\title{
PENGEMBANGAN APLIKASI MOBILE ACADEMIC INFORMATION SYSTEM (AIS) BERBASIS ANDROID UNTUK PENGGUNA DOSEN DAN MAHASISWA (Studi Kasus : Pusat Teknologi Informasi dan Pangkalan Data (Pustipanda) UIN Syarif Hidayatullah Jakarta)
}

\author{
Nicky Rolly ${ }^{1}$, Nashrul Hakiem² \\ ${ }^{1,2}$ Pusat Teknologi Informasi dan Pangkalan Data (PUSTIPANDA) UIN Syarif Hidayatullah Jakarta \\ ${ }^{2}$ Program Studi Teknik Informatika, Fakultas Sains dan Teknologi UIN Syarif Hidayatullah Jakarta \\ 1nicky@uinjkt.ac.id
}

\begin{abstract}
ABSTRAK
UIN Syarif Hidayatullah Jakarta sebagai lembaga pendidikan terkemuka telah memiliki sistem informasi akademik yang dapat menangani permasalahan pada bidang akademk, kemahasiswaan, keuangan dan kepegawaian. Sistem informasi akademik ini dapat diakses melalui browser pada pengguna komputer desktop, namun belum mendukung secara optimal untuk tampilan smartphone, sehingga user seringkali kesulitan untuk mengakses informasi yang ada pada sistem informasi akademik tersebut, dengan latar belakang tersebut penulis merancang sebuah aplikasi mobile sistem informasi akademik berbasis android yang dapat digunakan untuk mengakses menu pada role mahasiswa dan dosen sehingga dapat menampilkan informasi yang ada pada sistem informasi akademik dengan antar muka yang lebih optimal pada smartphone android, untuk pengembangannya aplikasi ini dibuat menggunakan bahasa pemrograman Java, Xml, dan Json dan terhubung secara real time ke database sistem informasi akademik. Metode pengembangan sistem yang digunakan adalah RAD (Rapid Application Development). Dengan aplikasi ini mahasiswa dan dosen dapat mengakses informasi dari sistem informasi akademik melalui aplikasi smartphone android, dan diharapkan aplikasi ini dapat menjadi cikal bakal pengembangan aplikasi android untuk semua modul dan fitur yang ada pada sistem informasi akademik UIN Syarif Hidayatullah Jakarta.
\end{abstract}

Kata kunci: Sistem informasi akademik, android, aplikasi mobile, RAD, AIS Mobile, AIS Android

\section{Pendahuluan}

Pada perkembangan teknologi saat ini, organisasi yang dianggap unggul dan kompetitif ialah organisasi yang menerapkan berbagai platform teknologi untuk menunjang proses bisnisnya, dengan penerapan berbagai platform teknologi organisasi dapat dengan mudah melakukan pross bisnis, pengolahan informasi dan penyampian informasi ke pengguna. Salah satu platform teknologi informasi yang sedang berkembang dan banyak dipakai oleh user di dunia saat ini adalah Android dimana platform besutan google ini mampu meraih banyak pengguna di berbagai tipe smartphone.

UIN Jakarta sebagai lembaga pendidikan terkemuka di Indonesia telah memiliki Sistem informasi akademik yang dikembangkan oleh pusat teknologi informasi dan pangkalan data, sistem informasi tersebut mampu menangani permasalahan pada bidang akademik, kemahasiswaan, keuangan dan kepegawaian. Sistem informasi akademik ini dapat diakses secara online di komputer melalui browser seperti Mozilla Firefox, Internet Explorer dan Google Chrome, namun belum mendukung secara optimal untuk tampilan smartphone sehingga user agak sulit untuk mengoperasikan aplikasi tersebut pada tampilan smartphone yang berukuran relatif lebih kecil dari komputer desktop.

Seiring dengan meningkatnya pengguna smartphone berbasis android di kalangan dosen, mahasiswa dan karyawan maka dirasa perlu untuk mengembangkan aplikasi sistem informasi akademik yang berjalan di smartphone berbasis android untuk memudahkan pengguna mengakses informasi secara mobile. Dengan adanya aplikasi Sistem informasi akademik berbasis android maka pengguna dapat secara optimal mengakses dan mengoperasikan aplikasi sistem informasi akademik pada perangkat smartphone berbasis android khususnya bagi Dosen dan Mahasiswa yang membutuhkan informasi yang cepat dan dapat diakses melalui perangkat mobile.

\section{LANDASAN TEORI}

\subsection{Android}

Android merupakan sistem operasi yang berisi middleware serta aplikasi-aplikasi dasar. Basis sistem operasi android yaitu kernel linux 2.6 yang telah diperbaharui untuk mobile device. Pengembangkan aplikasi android menggunakan bahasa pemrograman java. Yang mana konsep-konsep pemrograman java 
berhubungan dengan Pemrograman Berbasis Objek $(O O P))$. Selain itu pula dalam pengembangan aplikasi android membutuhkan software development kit (SDK) yang disediakan android, $S D K$ ini memberi jalan bagi programmer untuk mengakses application programming interface (API) pada android.

\subsection{Rapid Application Development (RAD)}

Rapid Application Development (RAD) adalah strategi siklus hidup yang ditujukan untuk menyediakan pengembangan yang jauh lebih cepat dan mendapatkan hasil dengan kualitas yang lebih baik dibandingkan dengan hasil yang dicapai melalui siklus tradisional [1]. RAD merupakan gabungan dari bermacam-macam teknik terstruktur dengan teknik prototyping dan teknik pengembangan joint application untuk mempercepat pengembangan sistem/aplikasi [2]. Dari definisi-definisi konsep RAD ini, dapat dilihat bahwa pengembangan aplikasi dengan menggunakan metode RAD ini dapat dilakukan dalam waktu yang relatif lebih cepat.

\subsubsection{Fase dan Tahapan Pengembangan RAD}

Menurut [3] terdapat tiga fase dalam RAD yang melibatkan penganalisis dan pengguna dalam tahap penilaian, perancangan, dan penerapan. Adapun ketiga fase tersebut adalah requirements planning (perencanaan syarat-syarat), RAD design workshop (workshop desain RAD), dan implementation (implementasi).

\subsubsection{Kelebihan dan kekurangan RAD}

Metode pengembangan sistem RAD relatif lebih sesuai dengan rencana pengembangan aplikasi yang tidak memiliki ruang lingkup yang besar dan akan dikembangkan oleh tim yang kecil. Namun, RAD pun memiliki kelebihan dan kekurangannya sebagai sebuah metodoligi pengembangan aplikasi. Berikut ini adalah kelebihan metodologi RAD menurut [4]:

- Penghematan waktu dalam keseluruhan fase projek dapat dicapai.

- RAD mengurangi seluruh kebutuhan yang berkaitan dengan biaya projek dan sumberdaya manusia.

- RAD sangat membantu pengembangan aplikasi yang berfokus pada waktu penyelesaian projek.

- Perubahan desain sistem dapat lebih berpengaruh dengan cepat dibandingkan dengan pendekatan SDLC tradisional.

- Sudut pandang user disajikan dalam sistem akhir baik melalui fungsi-fungsi sistem atau antarmuka pengguna.

- RAD menciptakan rasa kepemilikan yang kuat di antara seluruh pemangku kebijakan projek.
Sedangkan, mengacu pada pendapat [3], maka dapat diketahui bahwa kekurangan penerapan metode RAD adalah sebagai berikut:

Dengan metode RAD, penganalisis berusaha mepercepat projek dengan terburu-buru.

Kelemahan yang berkaitan dengan waktu dan perhatian terhadap detail. Aplikasi dapat diselesaikan secara lebih cepat, tetapi tidak mampu mengarahkan penekanan terhadap permasalahan-permasalahan perusahaan yang seharusnya diarahkan.

RAD menyulitkan programmer yang tidak berpengalaman menggunakan perangkat ini di mana programmer dan analyst dituntut untuk menguasai kemampuan-kemampuan baru sementara pada saat yang sama mereka harus bekerja mengembangkan sistem.

\subsection{Eclipse IDE}

Eclipse adalah sebuah IDE (Integrated Development Environment) untuk mengembangkan perangkat lunak dan dapat dijalankan di semua platform (platform-independent), Aplikasi Android di tulis dan dibangun dengan menggunakan Java, dengan begitu ada beberapa pilihan Aplication Building Tools. Baik dengan memakai IDE (Integrated Development Environment) atau dengan CLI (Command Line Interface).Akan tetapi pada saat ini OHA(Open Handset \ Alliance) dan Google sangat mendukung Eclipse sebagai IDE Java untuk membangun aplikasi android dibandingkan dengan IDE lain. Salah satu bukti adalah dirilisnya plugin ADT (Android Development Tools)untuk Eclipse .

\subsection{UML}

Unified Modeling Language, (UML) adalah merupakan sistem arsitektur yang bekerja dalam OOAD (Object-Oriented Analysis Design) dengan satu bahasa yang konsisten untuk menentukan, visualisasi, mengkontruksi dan mendokumentasi artifact(sepotong informasi yang digunakan atau dihasilkan dalam suatu proses rekayasa software, dapat berupa model, deskrispi, atau software) yang terdapat dalam sistem software. UML merupakan bahasa pemodelan yang paling sukses dari tiga metode Orientasi Obyek yang telah ada sebelumnya yaitu :

1.Grady Booch OOD (Object-Oriented Design)

2.Jim Rumbaugh OMT (Object Modeling Tecnique)

3.Ivar Jacobson OOSE (Object-Oriented Software Engineering

Menurut [5] "UML adalah bahasa pemodelan standar yang memiliki sintak dan semantik". Sedangkan menurut [6], "UML (Unified Modeling Language) adalah bahasa pemodelan untuk sistem atau perangkat lunak yang berparadigma (berorientasi objek)." Pemodelan (modeling) sesungguhnya digunakan untuk penyederhanaan permasalahan- 
permasalahan yang kompleks sedemikian rupa sehingga lebih mudah dipelajari dan dipahami.

Berdasarkan pendapat yang dikemukakan di atas dapat ditarik kesimpulan bahwa UML adalah sebuah bahasa yang berdasarkan grafik atau gambar untuk menvisualisasikan, menspesifikasikan, membangun dan pendokumentasian dari sebuah sistem pengembangan perangkat lunak berbasis Objek (Object Oriented programming).

\subsection{JSON}

JSON (JavaScript Object Notation) merupakan format yang ringan untuk memasukan data ke dalam sebuah variabel. Sangat mudah dimengerti dan diimplementasikan oleh manusia, dan mudah juga untuk komputer dalam melakukan parsingnya

JSON merupakan bagian dari bahasa pemrograman JavaScript (Standard ECMA-262 3rd Edition - December 1999). JSON merupakan format teks yang sepenuhnya independen tetapi menggunakan konvensi yang familiar dengan bahasa pemrograman dari keluarga-C, termasuk $\mathrm{C}, \mathrm{C}++, \mathrm{C}$, Java, JavaScript, Perl, Python, dan sebagainya. Kelebihan inilah yang membuat JSON menjadi sebuah bahasa data - interchange yang ideal.

\section{Metode Penelitian}

\subsection{Metode Pengembangan Sistem}

Pengembangan sistem dapat diartikan sebagai sebuah proses pengembangan terstandarisasi yang mendefinisikan satu set aktivitas, metode, praktik terbaik, dan perangkat terotomatisasi yang akan digunakan oleh para pengembang sistem dan manajer proyek untuk mengembangkan dan berkesinambungan memperbaiki sistem informasi dan perangkat lunak [2].

Dalam pengembangan ini, metodologi yang digunakan adalah Rapid Application Development (RAD). Adapun alasan penulis menggunakan metodologi ini karena pengembangan sistem ini akan lebih murah dalam hal biaya dan lebih cepat dalam implementasi serta melibatkan pengguna akhir dalam proses pengembangannya, sehingga tujuan utama sistem lebih terarah pengembangannya. Adapun langkah-langkah yang penulis lakukan dalam pengembangan sistem menggunkan RAD sebagai berikut:

\subsubsection{Fase Perencanaan dan Syarat - syarat}

Pada tahap ini penulis melakukan pengindentifikasian tujuan aplikasi atau sistem serta untuk mengindentifikasi syarat-syarat informasi yang ditimbulkan dari tujuan-tujuan tersebut yang terdiri dari analisis kebutuhan sistem, tujuan dan syaratsyarat. Proses ini dilakukan untuk mengetahui apa saja syarat-syarat dan kebutuhan yang dibutuhkan dalam pembuatan aplikasi untuk memenuhi tujuan dari pembuatan aplikasi.

\subsubsection{Fase Workshop Design}

Setelah mengetahui definisi aplikasi yang akan dirancang atau dibuat, maka tahapan berikutnya adalah melakukan perancangan (design). Perancangan di sini dimaksudkan untuk membuat pemodelan terhadap aplikasi yang dapat mewakili fase perencanaan syaratsyarat diatas. Desain yang dimaksud meliputi perancangan proses, aplikasi, database, daninterface. Untuk tampilan antarmuka (interface) aplikasi sendiri, penulis melakukan perancangan Graphical User Interface (GUI) dari aplikasi ini.

\subsubsection{Fase Implementasi}

Dalam fase dibawah ini akan dilakukan implementasi aplikasi pengenalan gaya tulisan diantaranya:

\section{Membangun Aplikasi}

Dalam tahap ini aplikasi dirancang dengan menggunakan bahasa pemrograman Android , database SQL Lite, menggunakan referensi pengembangan yang ada pada buku Algoritma dan Pemrograman dengan Bahasa Java [7] dan buku Pemrograman Android Blackbox [8].

\section{Menguji Aplikasi}

Pada tahap ini penulis melakukan penggujian atau testing. Untuk pengujian sistem dilakukan dengan metode blackbox testing, dimana peneliti melakukan input data pada sistem dan melihat output-nya apakah sesuai dengan sistem yang diharapkan. Alasan penulis menggunakan metode pengujian black-box karena berdasarkan kebutuhan sistem yang telah dijelaskan dihalaman sebelumnya, bahwa user hanya menginginkan suatu aplikasi ketika user meng-input variabel maka akan menghasilkan output yang diharapkan dengan tampilan yang user friendly tanpa menguji lebih dalam logika dari proses aplikasi tersebut.

\section{Hasil dan Pembahasan}

\subsection{Fase Perencanaan dan Syarat - Syarat}

Pada fase requirement planning akan diuraikan mengenai analisis sistem untuk memenuhi syaratsyarat perancangan dalam aplikasi yang akan dibuat. Perencanaan syarat-syarat tersebut terdiri atas analisis kebutuhan sistem, tujuan dan syarat-syarat. Proses ini dilakukan untuk mengetahui apa saja syarat-syarat dan kebutuhan yang dibutuhkan dalam pembuatan aplikasi untuk memenuhi tujuan dari pembuatan aplikasi 


\subsubsection{Analisa dan Kebutuhan Sistem}

Berdasarkan kebutuhan sistem secara umum, perangkat lunak yang akan dibangun harus memenuhi kebutuhan sebagai berikut:

1.Mampu mengambil data yang dibutuhkan dari database AIS (Academic Information System) UIN Jakarta untuk User Mahasiswa dan Dosen melalui web service.

2.Mampu berjalan pada platform sistem operasi Android

3.Dapat digunakan oleh User Dosen dan Mahasiswa

4.Pada menu Mahasiswa dapat menampilkan Jadwal kuliah dan data penilaian mahasiswa

5.Pada menu Dosen dapat menampilkan jadwal kuliah, penginputan nilai dan validasi KRS mahasiswa.

\subsubsection{Menentukan Tujuan}

Tujuan dari perancangan aplikasi ini adalah membuat suatu aplikasi Sistem informasi akademik berbasis android yang dapat mengambil dan memanipulasi data yang dibutuhkan oleh Dosen dan Mahasiswa dari Sistem Informasi Akademik UIN Jakarta melalui web service.

\subsubsection{Menentukan Syarat - syarat}

Syarat-syarat untuk mencapai tujuan dalam pengembangan aplikasi sistem informasi akademik berbasis android, meliputi hal-hal sebagai berikut:

1.Bahasa Pemrograman Java

2.Bahasa Pemrograman XML

3.Database menggunakan SQL Lite pada sisi aplikasi android

4.Web services dengan JSON.

\subsubsection{Analisis Sistem Yang Diusulkan}

Setelah melakukan analisis diatas untuk menjawab permasalahan-permasalahan yang dihadapi, peneliti bermaksud mengusulkan sebuah aplikasi untuk memudahkan user dalam mengakses informasi sistem informasi akademik melalui perangkat android. Usulan sistem yang dimaksud adalah sebagai berikut:

1. Membangun aplikasi sistem informasi akademik berbasis android yang dapat digunakan minimal pada perangkat ponsel dengan sistem operasi android versi 2.2 (Android Froyo)

2. Membangun aplikasi sistem informasi akademik yang dapat digunakan oleh user dosen dan mahasiswa untuk mengakses data akademis yang ada pada AIS uin jakarta

3. Membangun aplikasi sistem informasi akademi berbasi android yang dapat digunakan mahasiswa untuk melihat jadwal kuliah dan data penilaian

4. Membangun aplikasi sistem informasi akademik berbasis android yang dapat digunakan dosen untuk melihat perkuliahan yang diampu dan melakukan penilaian mahasiswa dan melakukan validasi KRS mahasiswa.

\subsection{Fase Workshop Design}

Pada fase workshop design ini terdapat tiga fase yang peneliti lakukan yaitu fase desain sistem, desain basis data, dan desain interface.

\subsubsection{Desain Sistem}

\subsubsection{Use Case}

Langkah-langkah yang akan digunakan dalam pemodelan use case.

Tabel 1. Identifikasi Aktor

\begin{tabular}{|l|l|l|}
\hline No & Aktor & Deskripsi \\
\hline 1 & Dosen & $\begin{array}{l}\text { Dosen adalah pihak yang } \\
\text { berhak mengakses menu } \\
\text { penilaian dan valdasi KRS }\end{array}$ \\
\hline 2 & Mahasiswa & $\begin{array}{l}\text { Mahasiswa adalah pihak } \\
\text { yang berhak mengakses } \\
\text { menu jadwal kuliah dan data } \\
\text { penilaiah mahasiswa }\end{array}$ \\
\hline
\end{tabular}

\subsubsection{Use Case Diagram}

Menggambarkan sejumlah external actors dan hubungannya ke use case yang diberikan oleh sistem. Use case adalah deskripsi fungsi yang disediakan oleh sistem dalam bentuk teks sebagai dokumentasi dari use case symbol namun dapat juga dilakukan dalam Activity diagrams.

Use case digambarkan hanya yang dilihat dari luar oleh actor (keadaan lingkungan sistem yang dilihat user dan bukan bagaimana fungsi yang ada di dalam sistem).

Usecase diagram sistem yang diusulkan, yaitu seperti gambar dibawah ini:

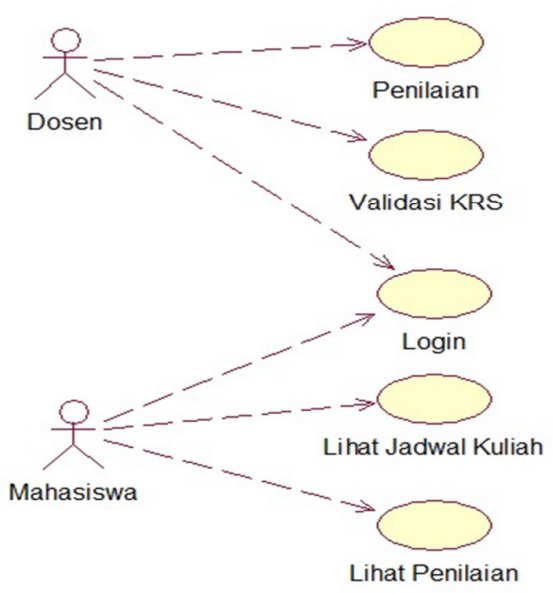

Gambar 1. Usecase Diagram 


\subsubsection{Identifikasi Use Case}

Tabel 2. Identifikasi Use Case

\begin{tabular}{|c|l|l|l|}
\hline No & $\begin{array}{c}\text { Use } \\
\text { Case } \\
\text { Name }\end{array}$ & \multicolumn{1}{|c|}{ Description } & Actor \\
\hline 1 & Login & $\begin{array}{l}\text { Use case ini } \\
\text { digunakan sebagai } \\
\text { authentication } \\
\text { untuk dapat } \\
\text { mengakses aplikasi } \\
\text { sesuai hak } \\
\text { aksesnya masing- } \\
\text { masing. }\end{array}$ & $\begin{array}{l}\text { Dosen, } \\
\text { wahasis }\end{array}$ \\
\hline 2 & $\begin{array}{l}\text { Valida } \\
\text { si KRS }\end{array}$ & $\begin{array}{l}\text { Use case ini } \\
\text { digunakan untuk } \\
\text { melakukan validasi } \\
\text { KRS }\end{array}$ & Dosen \\
\hline 3 & $\begin{array}{l}\text { Penilai } \\
\text { an }\end{array}$ & $\begin{array}{l}\text { Use case ini } \\
\text { digunakan untuk } \\
\text { melakukan input } \\
\text { nilai mahasiswa }\end{array}$ & Dosen \\
\hline 4 & $\begin{array}{l}\text { Lihat } \\
\text { Jadwal } \\
\text { Kuliah }\end{array}$ & $\begin{array}{l}\text { Use case ini } \\
\text { digunakan untuk } \\
\text { melihat jadwal } \\
\text { kuliah }\end{array}$ & $\begin{array}{l}\text { Mahasis } \\
\text { wa }\end{array}$ \\
\hline 5 & $\begin{array}{l}\text { Lihat } \\
\text { Penilai } \\
\text { Use case ini } \\
\text { digunakan untuk } \\
\text { melihat data } \\
\text { penilaian }\end{array}$ & Dosen \\
\hline
\end{tabular}

\subsubsection{Activity Diagram}

Activity diagram menggambarkan workflow proses dan urutan aktivitas dalam sebuah proses. Diagram ini mirip dengan flowcahart, keuntungan dengan dibuatnya diagram ini pada awal pemodelan untuk membantu memahami keseluruhan proses. Activity diagram juga bermanfaat untuk menggambarkan parallel behaviour atau menggambarkan interaksi beberapa use case.

Proses kerja dari sistem yang diusulkan dapat digambarkan dalam bentuk activity diagram. Berikut adalah activity diagram yang terdapat dalam aplikasi sistem informasi akademik berbasis Android.

\subsubsection{Sequence Diagram}

Sequence diagram menggambarkan interaksi antara sejumlah objek di dalam dan disekitar user berupa message yang digambarkan terhadap waktu. Sequence diagram terdiri antar dimensi vertikal (waktu) dan dimensi horizontal (objek-objek yang terkait).

\subsubsection{Class Diagram}

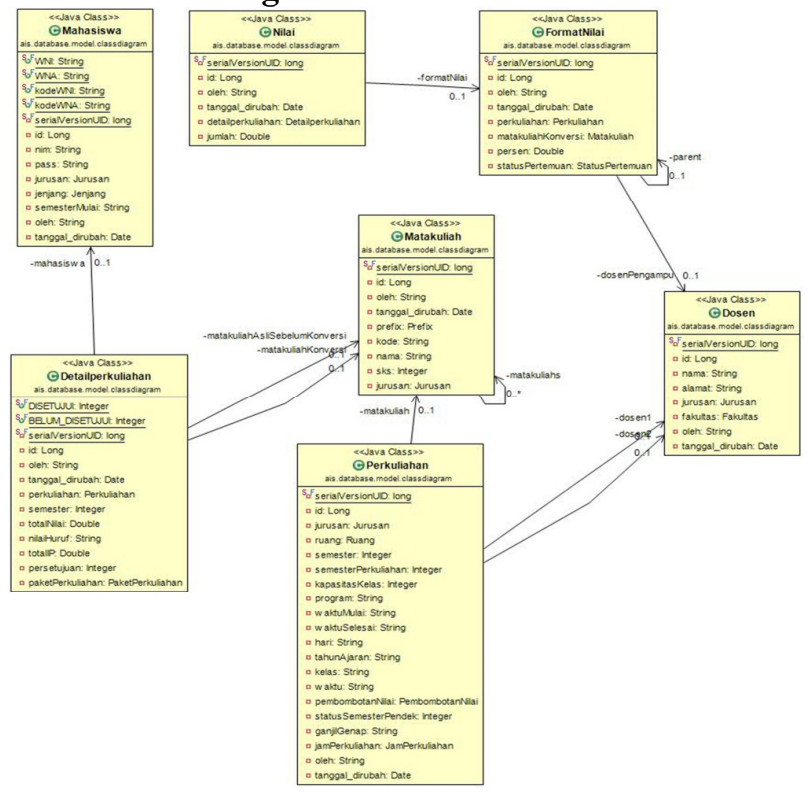

Gambar 2. Class Diagram

\subsubsection{Desain Perangkat Simulasi}

\subsubsection{Pembuatan Web Service Pada AIS}

Pada tahap ini penulis melakukan pengkodean pada aplikasi AIS agar aplikasi tersebut dapat mengeluarkan output json yang dapat di akses oleh aplikasi android dengan perantara web service melalui protokol internet, pengembangan ini menggunakan referensi yang ada pada buku Kolaborasi Dahsyat Android dengan PHP dan MySQL [9].

\subsubsection{Pembuatan Program AIS Android}

Pada tahap ini penulis melakukan pengkodean terhadap hasil rancangan yang sudah didefinisikan sebelumnya untuk dijadikan program antar muka aplikasi android, pembuatan aplikasi ini menggunakan Java dan Android library.

\subsection{Fase Implementasi}

Setelah tahap workshop design selesai, maka tahap berikutnya adalah mengimplementasikan hasil rancangan tersebut. Implementasi aplikasi dilakukan dengan dua cara pertama pada perangkat lunak emulator dan perangkat keras sesungguhnya (ponsel).

\section{KESIMPULAN DAN SARAN}

\subsection{Kesimpulan}

Aplikasi Sistem Informasi Akademik berbasis Android ini merupakan salah satu solusi yang dibuat untuk menampilkan data AIS (Academic Information System) yang dibutuhkan oleh Dosen dan Mahasiswa pada ponsel dengan sistem operasi berbasis android. 
Aplikasi ini menyediakan menu dan antar muka yang disesuaikan dengan kebutuhan Dosen untuk pengaksesan KRS mahasiswa dan penginputan nilai; sedangkan untuk Mahasiswa dapat digunakan untuk melihat nilai dan jadwal kuliah.

\subsection{Saran}

Fitur yang ada di Sistem Informasi Akademik berbasis android ini masih belum sempurna dan mencakup semua menu yang ada di AIS (Academic Information System), oleh karena itu masih banyak hal yang dapat dilakukan untuk mengembangkan apliaksi ini menjadi lebih baik lagi, antara lain :

1.Aplikasi sistem informasi akademik berbasis android baru mencakup menu untuk melihat KRS mahasiswa dan penilaian mahasiswa untuk user Dosen dan menu untuk melihat penilaian dan jadwal kuliah untuk user Mahasiswa, oleh karena itu masih banyak menu lain yang ada di AIS yang dapat diimplementasikan di Aplikasi Sistem Informasi Akademik berbasi Android.

2. Tampilan antar muka yang ada di Aplikasi sistem informasi akademik ini masih harus diperbaiki agar lebih menarik dan memudahkan pengguna dalam pengaksesan data yang dibutuhkan.

\section{DAFTAR PUSTAKA}

[1]R. McLeod, Jr. and E. Jordan, Systems Development: A Project Management Approach. New York: Wiley, 2002.

[2] J. Whitten and L. Bentley, Systems Analysis and Design Methods. New York: McGraw-Hill, 2005.

[3] Kenneth E. Kendall and J. E. Kendall, Analisis dan Perancangan Sistem. Jakarta: Indeks, 2003.

[4] G. M. Marakas, Systems Analysis \& Design: An Active Approach. Georg. New York: Irwin/McGraw-Hill, 2005.

[5] P. P. Widodo and Herlawati, Menggunakan UML, Unified Modeling Language by Prabowo Pudjo Widodo - Reviews, Discussion, Bookclubs, Lists. Bandung: Informatika, 2011.

[6] A. Nugroho, Rekayasa Perangkat Lunak Menggunakan UML dan Java. Yogyakarta: Andi, 2009.

[7] F. X. W. Y. Untoro, Algoritma \& Pemrograman dengan Bahasa Java. Yogyakarta: Graha Ilmu, 2010.

[8] Y. Murya, Pemrograman Android Black Box. Jakarta: Jasakom, 2013.

[9] A. D. Kasman, Kolaborasi Dahsyat ANDROID dengan PHP dan MySQL. Yogyakarta: Lokomedia, 2013. 